\title{
Features of forming the salt balance in rice fields with various parameters and designs of the Danube rice irrigation systems
}

\author{
Vasyl Turchenyuk ${ }^{1, *}$, Anatoliy Rokochinskiy ${ }^{1}$, Nataliia Prykhodko ${ }^{1}$, Pavlo $_{\text {Volk }}{ }^{1}$, and Oleh Meshyk ${ }^{2}$ \\ ${ }^{1}$ National University of Water and Environmental Engineering, Department of Water Engineering and Water Technologies, 33028, \\ Soborna 11, Rivne, Ukraine \\ ${ }^{2}$ Brest State Technical University, Department of Environmental Engineering, 224017, Moskovska 267, Brest, Belarus
}

\begin{abstract}
Ecological-reclamation state of rice irrigation systems harvest of cultivated crops determined by a number of factors, including natural (soil, topographical, hydrogeological, climatic factors) and technological (irrigation norm, designs and parameters of irrigation and drainage networks, etc.) factors. One of the main factors influencing the formation of rice yield which is traditionally grown by flooding technology is the efficiency of the rice irrigation system's design. Construction features of irrigation fields and their parameters (distances between the drains, depth of the drainage network) affect the intensity of the processes of salinization of soils and groundwater. Analysis of the components of salt balances of rice fields with different parameters and designs on example of the Danube rice irrigation systems showed that fields with the distances between the drains from 200 to 250 m have significant advantages over Krasnodar-type fields with the same parameters and over fields with $500 \mathrm{~m}$ distance between the drains creating optimal salt regime for rice and, accordingly, obtaining higher yields of rice. As on the card-checks with drainage with the distances between the drains $500 \mathrm{~m}$ uniform desalinization of soils on all area cannot be reached and yield of rice on them is close to $20 \mathrm{c} /$ ha such card-checks with drainage must be converted into card-checks with drainage with the distances between the drains $250 \mathrm{~m}$.
\end{abstract}

\section{Introduction}

The concept of the stable development of national economy envisages rational ecological and economic nature use guaranteeing the business operation without worsening environment and its preservation for generations to come. In this connection problems arising in the sphere of rice sowing in Ukraine are becoming of late especially urgent and call for speedy positive solutions.

In its time the main aim for creating native branch of rice sowing had been not only the satisfaction of the need for own rice but also the introduction in agricultural production of low efficient saline and bogged land in the Crimea, the Danube delta and areas adjoining the Black sea.

Industrial experiments have shown that such lands may be successfully used for rice irrigation systems (RIS) with obligatory application on them reasonable constructive decisions on ensuring a favorable ecological and reclamation condition on irrigated lands.

The construction of engineering rice irrigation systems in Ukraine began in the 70-s of the last century and at present their area amounts to about 62 thousand hectares (Crimea -30.8 thousand hectares, Kherson region -18 thousand hectares, Odessa region -14 thousand hectares).
Modern RIS is a complex set of water supply, drainage, regulative and other elements connected by a single technological process in combination with the rice fields, where the leading crop of rice crop rotation flooded rice and related overland crops are grown. The main element of any engineering rice system is a rice irrigation field. How well the design of the field is chosen and its parameters are selected depends on how successfully it will perform its functions, which are to create the optimal salt and water-air regime for rice and related crops.

The long-term studies have determined that drainage on saline lands RIS must meet the following basic requirements:

ensure, for 2-3 years, the salinization of the upper layer of soil 1.0-1.5 m to create favorable conditions for growing rice and related crops of rice crop rotation;

provide after drainage of the water from the checks the required norm of drainage not less than critical depth $(1.5-1.8 \mathrm{~m})$ at the beginning of the new irrigation season;

exclude the possibility of secondary salinization of soils in the fields occupied by related crops;

- create and maintain in the rice field optimal filtration rates for removal of salts from the active layer of soil.

Research by a number of authors $[1,2,3,4,5]$ showed that the desalination effect of the drainage network on the 
rice field cannot be estimated only by the amount of salts carried through it. In $[6,7,8,9,10]$ the unreasonableness of the study of soil salinization without taking into account the change of salt reserves in groundwater, especially at their close occurrence, is emphasized.

Based on these provisions, the most reliable and complete idea of the direction of salt processes in soils and groundwater, and hence an objective assessment of the drainage network can be obtained by drawing up a salt balance, which would take into account changes in salt reserves in soils, groundwater, inflows of salts with irrigation water and their removal with drainage water, other components of both income and expendable parts of such balance.

\section{Materials and methods}

The studies were performed according to standard methods [5]. The salt balances were compiled for a 3meter layer of soil and groundwater of each of the fields during the period of rice cultivation on them and based on water balance data.

The weighted average reserves of salts in soils and groundwater were determined on experimental fields also the period of related crops cultivation. In order to obtain comparable data, the thickness of the aeration zone was assumed to be $1.2 \mathrm{~m}$, and the thickness of the groundwater layer in the balance layer $-1.8 \mathrm{~m}$.

Studies of salt balance were conducted by us for 5 years in order to assess the effectiveness of rice fields with various parameters and designs on the Danube RIS located in the Odessa region (Fig. 1).

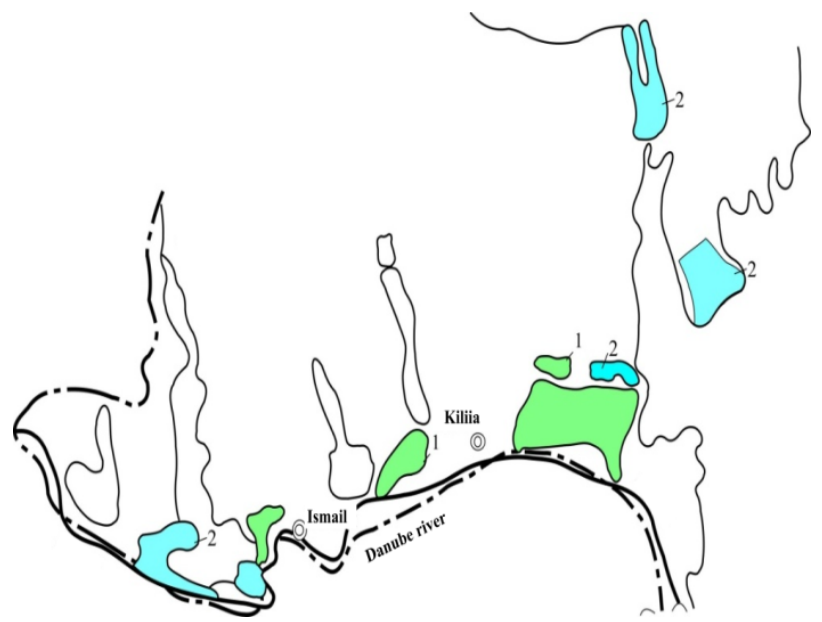

Fig. 2.1. Location of rice systems in Odessa region: 1 - existing; 2 - planned for the future

To solve the problems as the object of research was selected the Kiliia RIS with the total area of 3.45 thousand hectares, which is located on the territory of saline EastKiliia floods of the Danube delta.

Soils are represented mainly by sandy loam falling to the first regional water confining layer.

Before the construction of the Kiliia RIS the depth of occurrence of groundwater level was in the range from 0.0 to $2.5 \mathrm{~m}$ and their overall slope is directed towards the Danube River.

The content of salts in groundwater was in the range of 10-30 g/l, reaching $70 \mathrm{~g} / 1$ in individual cases. The mineralization of groundwater increased from swampy part of the floodplain to its central part.

During the long period of growing rice on the Kiliia RIS occurred desalination of groundwater. Their mineralization decreased to $1.5-15.0 \mathrm{~g} / \mathrm{l}$, which is explained by the relatively intense washing regime, which was created as the result of watering rice by flooding and drainage work. Only in small areas there was a desalinization of ground water up to $30 \mathrm{~g} / \mathrm{l}$.

The Kiliia RIS was built according to the well-known scheme of irrigation cards of the Krasnodar-type (KTC) and card-checks with drainage (CCD) with one-side and two-side command.

The distance between the channels, depending on the soil-hydrogeological conditions, was $200-500 \mathrm{~m}$ and the depth of the card drains $-1.5-1.7 \mathrm{~m}$. The KTC is the most common type of irrigation cards in the RIS of Ukraine.

Schemes of CCD and KTC are given in Fig.2.
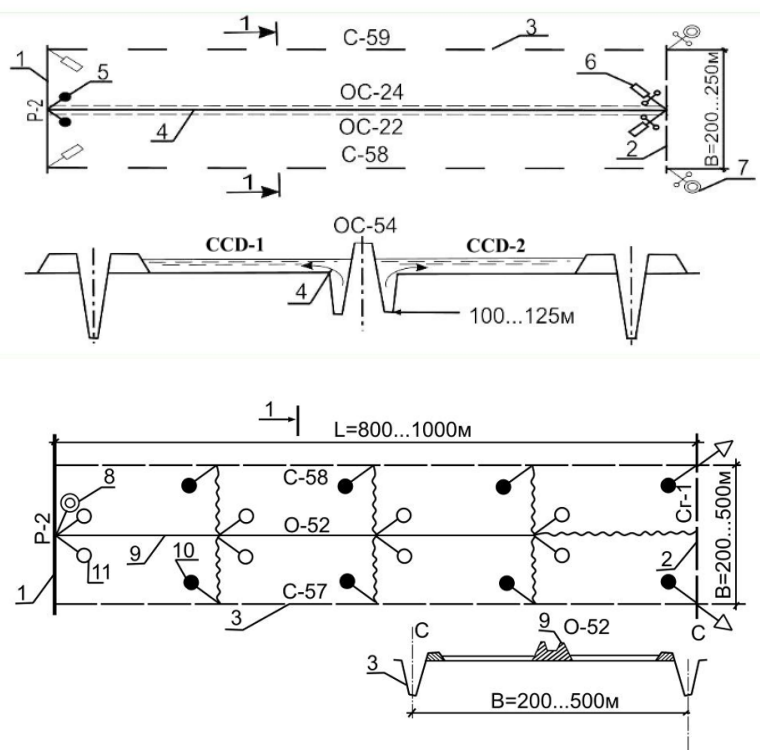

Fig. 2. Schemes of experimental card-check with drainage (CCD) and Krasnodar-type card (KTC) on the Danube rice systems: 1 - distribution channel; 2 - discharge channel; 3 - carddrain (CCD), or drain-discharge (KTC); 4 - irrigator-discharge of unilateral command; 5 - water outlet from the distribution channel to the irrigator-discharge; 6 - water outlet from the irrigator-discharge to the discharge channel; 7- water outlet from the card-drain to the discharge channel; 8 - water outlet from the distribution channel to the card-irrigator; 9 - cardirrigator; 10 - water outlet from the check to the discharge channel; 11 - water outlet from the card-irrigator to the KTC.

The research was conducted on three experimental sites. Shortened flooding was maintained in all areas during rice cultivation.

The first site consisted of two CCD with a one-way command irrigators-discharge, average depth of which was $0.7 \mathrm{~m}$, and distance between the drains $-200 \mathrm{~m}$. As a control, there was KTC with the card-irrigators of 
bilateral command and distance between the drains $200 \mathrm{~m}$.

The second site also consisted of two CCD and KTC, but the distance between the drains was $250 \mathrm{~m}$.

The third site consisted of two CCD with irrigatorsdischarge of unilateral command and the distance between the drains for the first CCD was $250 \mathrm{~m}$, and for the second - $500 \mathrm{~m}$.

Field studies conducted by us and other scientists [11, $12,13,14]$ on the rice systems of the Danube delta showed that features of motion of filtration streams on irrigation cards during the maintenance of the water layer is that in the part of their area formed a zone of groundwater lifting (along the irrigation channels) and a stagnant zone - in the center of the check, active movement of groundwater occurs only on the part of the area that adjoins directly to the drainage channel (Fig. 3).

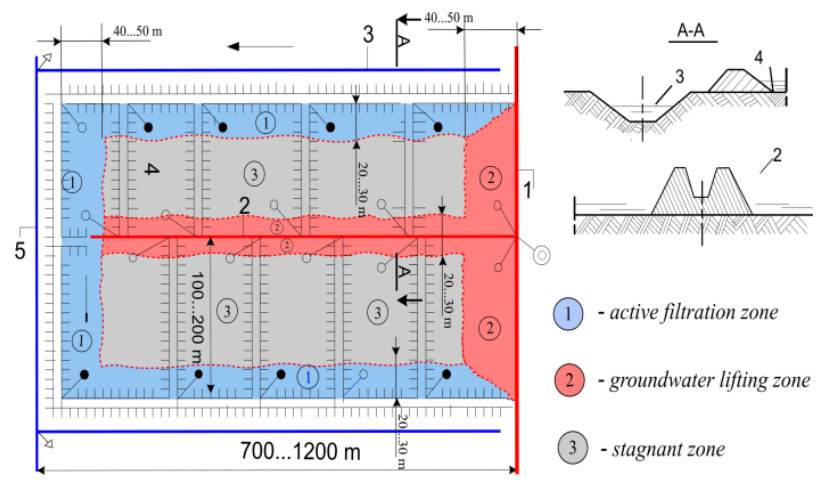

Fig. 3. Scheme of formation of characteristic zones of filtration on the rice check: 1 - distribution channel; 2 - card irrigator of bilateral command; 3 - card drainage and discharge channel; 4 check; 5 - sectional drainage and discharge channel.

The dimensions of these zones are determined by the hypsometric characteristics of the irrigation channels, depth of drains and water levels in them, and by size of the irrigation card.

The presence of such zones indicates irregular drainage on the area of the irrigation card. The total area that is practically doesn't drained is more than $60 \%$ of the area of the irrigation card. Calculations of filtration losses from the drainage zone, according to the schedule of rates, indicated that their volume from the drained strip is about $70 \%$ of their total volume.

\section{Results and discussions}

On the basis of annual salt balances were compiled averaged salt balances for fields of various parameters and designs (Table 1, 2, 3). The analysis of salt balances was carried out by assessing the structure and dynamics of their main components.

Comparing the change in salt reserves in the $1.2 \mathrm{~m}$ layer of soils on CCD and KTC with distances between the drains $200 \mathrm{~m}$ (site № I), we can note a higher intensity of soil desalinization. In general, for the entire period of observations and for each of the irrigation seasons with treatment of rice with herbicides, it was higher than on KTC by an average of 4\% (Table 1). In the site № 2 (distances between the drains $250 \mathrm{~m}$ ) also recorded the removal of salts at $8 \%$ higher on CCD than on KTC on average for each of the seasons of rice cultivation (Table 2).

Table 1. Salt balance of CCD and KTC with distances between the drains $200 \mathrm{~m}$ (five-years observation period).

\begin{tabular}{|c|c|c|c|c|}
\hline \multirow{2}{*}{ Elements of salt balance } & \multicolumn{4}{|c|}{ B $=\mathbf{2 0 0}$ m } \\
\cline { 2 - 5 } income part & \multicolumn{2}{|c|}{ KTC } \\
\cline { 2 - 5 } t/ha & t/ha & $\%$ \\
\hline $\begin{array}{c}\text { Reserves of salts in the } \\
\text { soil in April in the layer } \\
1.2 \text { m }\end{array}$ & 31.60 & 32.2 & 41.91 & 33.0 \\
\hline $\begin{array}{c}\text { Reserves of salts in } \\
\text { groundwater in April in } \\
\text { the layer 1.8 m }\end{array}$ & 55.53 & 56.5 & 74.70 & 58.8 \\
\hline $\begin{array}{c}\text { Receipt of salts with } \\
\text { irrigation water }\end{array}$ & 9.63 & 9.8 & 8.91 & 7.0 \\
\hline $\begin{array}{c}\text { Receipt of salts with } \\
\text { fertilizers }\end{array}$ & 1.50 & 1.5 & 1.50 & 1.2 \\
\hline $\begin{array}{c}\text { Total salts in the balance } \\
\text { layer (3m) }\end{array}$ & 98.26 & 100.0 & 127.0 & 100.0 \\
\hline \multicolumn{3}{|c|}{ expendable part } & \\
\hline $\begin{array}{c}\text { Reserves of salts in } \\
\text { November in the layer } 1.2 \\
\text { m }\end{array}$ & 24.36 & 24.8 & 37.03 & 29.2 \\
\hline $\begin{array}{c}\text { Reserves of salts in } \\
\text { groundwater in November } \\
\text { in the layer 1.8 m }\end{array}$ & 40.25 & 40.9 & 61.21 & 48.2 \\
\hline $\begin{array}{c}\text { Removal of salts with } \\
\text { drainage water }\end{array}$ & 34.07 & 34.6 & 24.35 & 19.2 \\
\hline $\begin{array}{c}\text { Removal of salts with } \\
\text { waste water }\end{array}$ & 1.83 & 1.8 & 2.90 & 2.3 \\
\hline $\begin{array}{c}\text { Removal of salts with the } \\
\text { harvest }\end{array}$ & 1.24 & 1.3 & 1.19 & 0.9 \\
\hline $\begin{array}{c}\text { Salt exchange with the } \\
\text { lower horizons }\end{array}$ & -3.49 & -3.5 & 0.34 & 0.3 \\
\hline $\begin{array}{c}\text { Total salts in the balance } \\
\text { layer (3 m) }\end{array}$ & 98.26 & 100.0 & 127.02 & 100.0 \\
\hline
\end{tabular}

Comparison of the intensity of the reduction of salt reserves in the card- checks with distances between the drains $200 \mathrm{~m}, 250 \mathrm{~m}$ and $500 \mathrm{~m}$ can be carried out only in relative terms, because the initial salt reserves in these areas differed significantly. On average, during the rice growing season with flooding the salt reserves decreased on $7-9 \%$ for $\mathrm{CCD}$, regardless of, practically, the value of distances between the drains. Although in the first years after the reconstruction of rice systems, during which there was a deepening of drainage network, the reduction of salt reserves was more intense.

At the same time, more intensive salt accumulation was observed the period of related crops cultivation on CCD with distances between the drains $500 \mathrm{~m}$ than on CCD with - $250 \mathrm{~m}$ and $200 \mathrm{~m}$, which further negatively affected on the rice yield.

Observation of changes in salt reserves in groundwater of all experimental site showed that they are as well as changes in salt reserves in soils are characterized by a number of features caused by the deepening of the drainage network, namely: the highest intensity of salt 
removal in the first year of rice cultivation after reconstruction; significant reduction of salt reserves compared to the original. During the period of crop rotation cultivation there was some increase in salt reserves in groundwater.

Table 2. Salt balance of CCD and KTC with distances between the drains $250 \mathrm{~m}$ (five-years observation period).

\begin{tabular}{|c|c|c|c|c|}
\hline \multirow{2}{*}{ Elements of salt balance } & \multicolumn{4}{|c|}{ B $=250$ m } \\
\cline { 2 - 5 } & \multicolumn{2}{|c|}{ CCD } & \multicolumn{2}{c|}{ KTC } \\
\cline { 2 - 5 } t/ha & \% & t/ha & \% \\
\hline \multicolumn{4}{|c|}{ expendable part } \\
\hline $\begin{array}{c}\text { Reserves of salts in the soil in April } \\
\text { in the layer 1.2 m }\end{array}$ & 41.49 & 41.2 & 38.42 & 38.5 \\
\hline $\begin{array}{c}\text { Reserves of salts in groundwater in } \\
\text { April in the layer 1.8 m }\end{array}$ & 48.58 & 48.3 & 51.04 & 51.2 \\
\hline $\begin{array}{c}\text { Receipt of salts with irrigation } \\
\text { water }\end{array}$ & 9.09 & 9.0 & 8.80 & 8.8 \\
\hline $\begin{array}{c}\text { Receipt of salts with fertilizers } \\
\text { Total salts in the balance layer (3m) }\end{array}$ & 1.46 & 1.5 & 1.43 & 1.4 \\
\hline $\begin{array}{c}\text { Reserves of salts in November in } \\
\text { the layer 1.2 m }\end{array}$ & 32.33 & 32.1 & 37.65 & 37.8 \\
\hline $\begin{array}{c}\text { Reserves of salts in groundwater in } \\
\text { November in the layer 1.8 m }\end{array}$ & 34.82 & 34.6 & 37.76 & 37.9 \\
\hline $\begin{array}{c}\text { Removal of salts with drainage } \\
\text { water }\end{array}$ & 27.76 & 27.6 & 21.90 & 21.9 \\
\hline Removal of salts with waste water & 1.77 & 1.8 & 2.20 & 2.2 \\
\hline Removal of salts with the harvest & 1.25 & 1.2 & 1.15 & 1.1 \\
\hline $\begin{array}{c}\text { Salt exchange with the lower } \\
\text { horizons }\end{array}$ & 2.69 & 2.7 & -0.97 & -0.9 \\
\hline $\begin{array}{c}\text { Total salts in the balance layer (3 } \\
\text { m) }\end{array}$ & 100.62 & 100.0 & 99.69 & 100.0 \\
\hline
\end{tabular}

Table 3. Salt balance of CCD with distances between the drains $500 \mathrm{~m}$ (five-years observation period)

\begin{tabular}{|c|c|c|}
\hline \multirow{3}{*}{ Elements of salt balance } & \multirow{2}{*}{\multicolumn{2}{|c|}{$\frac{\mathrm{B}=500 \mathrm{~m}}{\mathrm{CCD}}$}} \\
\hline & & \\
\hline & t/ha & $\%$ \\
\hline \multicolumn{3}{|l|}{ income part } \\
\hline $\begin{array}{l}\text { Reserves of salts in the soil in April in the layer } \\
1.2 \mathrm{~m}\end{array}$ & 98.86 & 38.5 \\
\hline $\begin{array}{c}\text { Reserves of salts in groundwater in April in the } \\
\text { layer } 1.8 \mathrm{~m}\end{array}$ & 147.54 & 57.5 \\
\hline Receipt of salts with irrigation water & 8.55 & 3.3 \\
\hline Receipt of salts with fertilizers & 1.50 & 0.5 \\
\hline Total salts in the balance layer $(3 \mathrm{~m})$ & 256.45 & 100.0 \\
\hline \multicolumn{3}{|l|}{ expendable part } \\
\hline $\begin{array}{c}\text { Reserves of salts in November in the layer } 1.2 \\
\mathrm{~m}\end{array}$ & 79.02 & 30.8 \\
\hline $\begin{array}{c}\text { Reserves of salts in groundwater in November } \\
\text { in the layer } 1.8 \mathrm{~m}\end{array}$ & 127.90 & 49.8 \\
\hline Removal of salts with drainage water & 41.16 & 16.0 \\
\hline Removal of salts with waste water & 2.14 & 0.8 \\
\hline Removal of salts with the harvest & 0.88 & 0.3 \\
\hline Salt exchange with the lower horizons & 5.35 & 2.0 \\
\hline Total salts in the balance layer $(3 \mathrm{~m})$ & 256.45 & 100.0 \\
\hline
\end{tabular}

Comparison of changes in salt reserves on CCD and
KTC with distances between the drains $200 \mathrm{~m}$ showed that seasonal removal of salts from groundwater during the period of rice cultivation was higher on CCD on the average for all period of observation by $6.94 \%$ in comparison with KTC, and in separate years exceeded $10 \%$. And although even if on KTC was a significant desalinization, but at the end of the study the salt reserves were higher than on CCD. This advantage of CCD is explained by its higher drainage during drying.

A similar situation with regard to the reduction of the amount of salts in groundwater was observed in the site № 2 (distances between the drains $250 \mathrm{~m}$ ) where the CCD also showed a higher intensity of desalinization in comparison with KTC.

Comparison of the intensity of reduction of salt reserves for $\mathrm{CCD}$ with different distances between the drains $200 \mathrm{~m}$ and $250 \mathrm{~m}$ showed that it practically not differ and made $19.08-24.81 \%$ from the original salt reserves and in 2 times exceeding this indicator for distances between the drains $500 \mathrm{~m}$, where it averaged only $11.41 \%$ of the original salt reserves. Given such a low rate of groundwater desalination at CCD with distances between the drains $500 \mathrm{~m}$ as well as the fact that at the end of the study the salt supply in the groundwater remained significant, we can conclude that under such circumstances it's not possible to achieve the desired groundwater desalination even in the near future.

Annually, the experimental sites received an average of 8.55 to $9.69 \mathrm{t} / \mathrm{ha}$ of salts with irrigation water, which was up to $9.8 \%$ of the income part of the salt balance (Table 1, 2, 3) and, in practice it does not significantly depend on the parameters and designs of rice fields.

The receipt of salts with fertilizers on the experimental sites varied from 1.43 to $1.50 \mathrm{t} / \mathrm{ha}$, which averaged up to $1.53 \%$ of the income part of the salt balance (Table 1, 2, 3 ) and has no significant effect on the formation of salt balance.

Removed salts from soils and groundwater of the balance layer of the experimental sites with drainage runoff varied during the observation period in a wide range, averaged up to $34.67 \%$ of the expendable part of the salt balance and was the main factor influencing the intensity of salt reduction in soils and groundwater.

Comparison of the amount of salts removed with the drainage runoff on the $\mathrm{CCD}$ and KTC with distances between the drains $200 \mathrm{~m}$ and $250 \mathrm{~m}$ showed the significant advantage of CCD. The average seasonal removal of salts on CCD with distances between the drains $200 \mathrm{~m}$ was higher by $13.9 \%$, and with $250 \mathrm{~m}$ - by $2.4 \%$ higher than on KTC with the same parameters (Table 1, 2).

Comparison of the removal of salts with the drainage runoff on the CCD with different distances between the drains showed that with increasing the distances between the drains it decreases significantly. The main reason for the greater removal of salts with drainage runoff on CCD in comparison with KTC with distances between the drains $200 \mathrm{~m}$ and $250 \mathrm{~m}$ is the presence on the CCD the irrigator-discharge, which plays the role of shallow drainage during the part of the irrigation season. The amount of salts removed by the irrigator-discharge was up to $14.36 \%$ of the total amount of salts removed from the 
CCD by the whole drainage network (Table 4).

If on the CCD along the irrigator-discharge there was desalinization of soils and groundwater, then on KTC in the central part there was contrary process - salinization. These facts indicate that there is a significant advantage of CCD over KTC in terms of ensuring optimal salt regime.

Removal of salts from the experimental sites with waste water there were in ten times less than removal of salts from drainage water. This averaged only 1.77 $1.90 \mathrm{t} /$ ha during the season and did not exceed $2.28 \%$ of the expendable part of the salt balance (Table 1,2,3). This indicator of the salt balance did not depend much on the parameters and designs of rice fields, but depended mainly on the original salinity of the upper soil horizon.

Removal of salts with the rice harvest over the years of research was 0.91-1.25 t/ha and did not exceed an average of $1.3 \%$ of the expendable part of the salt balance.

Table 4. Removal of salts from CCD on the experimental sites through irrigators-discharge during the season (April November).

\begin{tabular}{|c|c|c|c|c|c|}
\hline \multirow{3}{*}{$\begin{array}{c}\text { № } \\
\text { experimental } \\
\text { site }\end{array}$} & \multirow{3}{*}{$\begin{array}{c}\text { № } \\
\text { CCD }\end{array}$} & \multirow{3}{*}{$\begin{array}{l}\text { Distances } \\
\text { between the } \\
\text { drains, } \\
\text { m }\end{array}$} & \multicolumn{3}{|c|}{$\begin{array}{l}\text { Removed salts from } \\
\text { CCD with the } \\
\text { drainage runoff }\end{array}$} \\
\hline & & & \multirow{2}{*}{$\begin{array}{c}\text { total, } \\
\text { t/ha }\end{array}$} & \multicolumn{2}{|c|}{$\begin{array}{l}\text { irrigator- } \\
\text { discharge }\end{array}$} \\
\hline & & & & t/ha & $\%$ \\
\hline \multirow{2}{*}{1} & CCD-1 & 200 & 35.61 & 1.80 & 5.06 \\
\hline & CCD-2 & 200 & 32.53 & 1.58 & 4.85 \\
\hline \multirow{2}{*}{2} & CCD-1 & 250 & 28.65 & 3.70 & 12.94 \\
\hline & CCD-2 & 250 & 26.88 & 3.86 & 14.36 \\
\hline \multirow[b]{2}{*}{ J } & CCD-1 & 250 & 54.26 & 5.87 & 10.82 \\
\hline & CCD-2 & 500 & 41.15 & 4.41 & 10.72 \\
\hline
\end{tabular}

Actual production data on ecological and reclamation condition on irrigated lands of the Danube RIS are given in Table 5.

Table 5. Ecological and reclamation condition on irrigated lands of the Danube RIS (at the beginning of the growing season of 2016).

\begin{tabular}{|c|c|c|c|c|}
\hline \multirow[b]{2}{*}{$\begin{array}{l}\text { Irrigation } \\
\text { system }\end{array}$} & \multirow{2}{*}{ 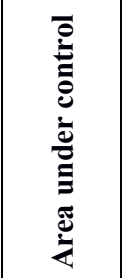 } & \multicolumn{3}{|c|}{$\begin{array}{l}\text { Ecological and reclamation } \\
\text { condition on irrigated lands, ha }\end{array}$} \\
\hline & & 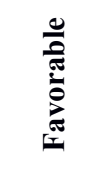 & 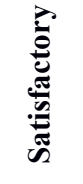 & 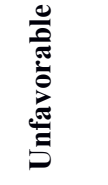 \\
\hline \multicolumn{5}{|c|}{ Kiliia region } \\
\hline Kiliia RIS-1 & 3317 & - & 2894 & 423 \\
\hline Kiliia RIS-2 & 1515 & 605 & 910 & - \\
\hline Liskovska RIS & 3859 & - & 3091 & 768 \\
\hline $\begin{array}{c}\text { Kiliisko- } \\
\text { Maiakska RIS }\end{array}$ & 1026 & - & 1026 & - \\
\hline Michurinska RIS & 1016 & 356 & 587 & 73 \\
\hline \begin{tabular}{|l|} 
Rice area \\
\end{tabular} & 135 & - & 135 & - \\
\hline \multirow{2}{*}{ Total } & \begin{tabular}{|l|l|} 
ha & 10868 \\
\end{tabular} & 961 & 8643 & 1264 \\
\hline & \begin{tabular}{|l|l|}
$\%$ & 100 \\
\end{tabular} & 9 & 80 & 12 \\
\hline \multicolumn{5}{|c|}{ Ismail region } \\
\hline Kyslytska RIS & 2810 & 638 & 1815 & 357 \\
\hline \multirow{2}{*}{ Total } & \begin{tabular}{|l|l|} 
ha & 2810 \\
\end{tabular} & 638 & 1815 & 357 \\
\hline & \begin{tabular}{|l|l|}
$\%$ & 100 \\
\end{tabular} & 23 & 65 & 12 \\
\hline
\end{tabular}

Production data showed that according to assessment criteria of actual ecological and reclamation stability of irrigated lands (depth and mineralization of groundwater, their hydrochemical composition, degree of salinity of soils), a significant part of the Danube RIS area is unstable.

\section{Conclusions}

1. With the distances between the drains $200 \mathrm{~m}$ and 250 $\mathrm{m}$ on CCD there is a more intensive desalination of soils and ground waters, than on KTC with the same parameters. The intensity of desalination at CCD with distances between the drains $200 \mathrm{~m}$ and $250 \mathrm{~m}$ differs insignificantly. With the distances between the drains 500 $\mathrm{m}$ it is impossible to achieve high rates of desalinization of soils and ground waters even in the conditions of CCD.

2. The fact that the desalination of soils and groundwater in all years of observations in sites with the distances between the drains $200 \mathrm{~m}$ and $250 \mathrm{~m}$ was more significant on CCD than on KTC indicates the advantage of CCD in terms of creating more favorable reclamation situation. This advantage of CCD is explained by the fact that during part of the irrigation season and part of the not irrigation season it is drained around the perimeter, thanks to the irrigator-discharge arranged on it, which acts as a shallow (up to $0.7 \mathrm{~m}$ ) drain.

3. Due to the fact that at CCD with the distances between the drains $200 \mathrm{~m}$ and $250 \mathrm{~m}$ desalination of soils occurred more intensively than on KTC the rice yield on them was on average $6 \mathrm{c} /$ ha higher.

4. As on the CCD with the distances between the drains $500 \mathrm{~m}$ uniform desalinization of soils on all area cannot be reached and yield of rice on them is close to 20 c/ha such CCD must be converted into CCD with the distances between the drains $250 \mathrm{~m}$.

\section{References}

1. V. B. Zaitsev, Risovaya orositelnaya sistema (Rice irrigation system). (Kolos, Moscow, 1975)

2. G. Balakay, O. Boreshevskaya, M. Mironchenko, Meliorativnoe sostoyanie risovyih orositelnyih sistem i neobhodimyie meropriyatiya po uvelicheniyu proizvodstva risa na yuge Rossii (Reclamation state of rice irrigation systems and the necessary measures to increase rice production in the south of Russi). Bulletin of Agrarian Science of the Don. 3, 113-120 (2010).

3. Abikenova Saltanat, Yespolov Tlektes, Aleksey Rau, Kalybekova Yessenkul, Zhanashev Issabek, Watersaving Technology of Rice Irrigation on Kazakstan Rice Systems. Biosciences, Biotechnology Research Asia. 12, 2459-2465 (2015). doi: http://dx.doi.org/10.13005/bbra/1924

4. Mathias Marcos, Hussain Sharifi, Stephen R. Grattan, Bruce A. Linquist, Spatio-temporal salinity dynamics and yield response of rice in water-seeded rice fields. 
Agricultural Water Management. 195, 37- 46 (2018). doi: 10.1016/j.agwat.2017.09.016

5. V. A. Stashuk, A. M. Rokochinsky, L. M. Granovsky (ed.), Rys v Ukraini (Rice in Ukraine). (OLDI-PLUS, Kherson, 2014)

6. G. N. Paudyal, G. N. Pandit, D. S, A. Goto, Optimization of design of on-farm channel network in an irrigation area. Irrigation and Drainage Systems. 5, 383-395 (1991). doi: https://doi.org/10.1007/BF01102834

7. S. P. Mendus, P. I. Mendus, A. M. Rokochinsky, Otsinka melioratyvnoho stanu ta efektyvnosti rysovykh system (Estimation of the meliorative state and efficiency of rice systems). Hydromelioration and hydrotechnical construction: collection of scientific works. 32, 38-49 (2007)

8. V. A. Kovda, Problems of combating desertification and salinization of irrigated lands (Problemyi borbyi s opustyinivaniem i zasoleniem oroshaemyih zemel), (Kolos, Moscow, 1984)

9. S. Yakuba, Optimization parameters of rice irrigation systems to ensure energy security of the water management complex of the Lower Kuban (Parametryi optimizatsii risovyih orositelnyih sistem dlya obespecheniya energeticheskoi). Polythematic online electronic scientific journal of the Kuban State Agrarian University. 34, 109-113 (2007)

10. Z. Katambara, F. C. Kahimb, W. B. Mbungu, R. Paul, M. Maugo, Optimizing system of rice intensification parameters using aquacrop model for increasing water productivity and water use efficiency in rice production. Intercarto. Intergis. 20, 357 (2014). doi: https://doi.org/10.24057/2414-9179-2014-1-20-357
11. S. M. Kropivko, Issledovanie effektivnosti kart-chekov shirokogo fronta zatopleniya s drenazhem (na primere risovyih orositelnyih sistem deltyi Dunaya) (Research of efficiency of cards-checks of a wide front of flooding with drainage (on an example of rice irrigation systems of the Danube delta)). (Ukrainian Institute of Hydraulic Engineering and Land Reclamation, Kyiv, 1987)

12. P. I. Mendus: Vliyanie orositelnyih kanalov raznyih konstruktsiy na k.p.d. risovyih sistem i prilegayuschie territorii $v$ usloviyah deltyi Dunaya (Influence of irrigation canals of different designs on efficiency of rice systems and adjacent territories in the conditions of the Danube delta). (Ukrainian Institute of Water Management Engineers, Rivne, 1975)

13. S. P. Mendus: Obhruntuvannia neobkhidnosti ta posylennia drenovanosti polyvnykh kart rysovykh system (na prykladi Prydunaiskykh rysovykh zroshuvalnykh system) (Substantiation of necessity and strengthening of drainage of irrigation maps of rice systems (on the example of Danube rice irrigation systems)). (National University of Water and Environmental Engineering, Rivne, 2012)

14. S. M. Goncharov, L.S. Kotelchuk, Vodno-solevoy balans kak osnova dlya naznacheniya i otsenki meliorativnyih meropriyatiy $\mathrm{v}$ usloviyah poymennyih i deltovyih territoriy yuzhnyih rek Ukrainyi (Watersalt balance as a basis for the appointment and assessment of reclamation measures in the conditions of floodplain and delta areas of the southern rivers of Ukraine). Agricultural use of floodplains of southern rivers of the European part of the USSR. 154-162 (1975) 